\title{
Analysis of differences in pain and disability in people with adult scoliosis and nonspecific low back pain
}

\author{
L Bissolotti ${ }^{1,3^{*}}$, V Sani ${ }^{1,3}$, M Gobbo ${ }^{2,3}$, C Orizio $^{2,3}$ \\ From 9th International Conference on Conservative Management of Spinal Deformities - SOSORT 2012 \\ Annual Meeting \\ Milan, Italy. 10-12 May 2012
}

\section{Background}

The cumulative effect of the aging process in patients with juvenile scoliosis and the appearance of new cases in adult scoliosis (AS)elicits great interest among clinicians and surgeons involved in management of spinal deformities[1]. Advances in scoliosis management are constantly required

\section{Aim}

The aim of this paper is to compare pain, and disability, in patients with AS and nonspecific low back pain (NL).

\section{Methods}

Cotrel method was used to assess Cobb angle (CA) on plain $\mathrm{x}$-ray. Only patients with Cobb angle $>15^{\circ}$ were included in the study. Numeric Rating Scale (NRS, 0-10) was used to assess pain during last 48 hrs. Roland Morris Questionnaire (RMQ) and Oswestry Disability Index (ODI1.0) were used to evaluate disability.

\section{Results}

AS-Group included 40 patients, 10 men and 30 women (age 61.8 \pm 11.5 years, BMI $23.6 \pm 2.8 \mathrm{~kg} / \mathrm{m} 2$ ). A single curve was present in 32 patients $(80 \%)$. Primary curve averaged $27.1 \pm 11.5^{\circ}$ (range, $15-63^{\circ}$ ), thoracic curve averaged $25.5 \pm 22.3^{\circ}$ (range, $8-58^{\circ}$ ). NL-Group included 40 patients, 9 men and 31 women (age $58.2 \pm 10.9$ years, BMI $23.9 \pm 3.2 \mathrm{~kg} / \mathrm{m} 2)$. NRS score for AS-group was $5.9 \pm 1.8$ (range, 2-10), while for NL group it was $5.1 \pm 2.2(\mathrm{p}>0.05)$. According to RMQ, the disability derived by low back

'Servizio di Recupero e Rieducazione Funzionale, Casa di Cura Domus Salutis, Brescia, Italy

Full list of author information is available at the end of the article pain presented a mean value of $11.3 \pm 4.4$ points in ASgroup (range, 2-22), while in NL-group it averaged $11.5 \pm 5.5$ points ( $>0.05$ ). According to ODI1.0 AS-group presented a disability score of $33.9 \pm 17.6 \%$, while in NLgroup it was $32.6 \pm 18.8 \%$ ( $>0.05$ ). Sciatic pain was present in $27 \%$ of AS-Group and in $47 \%$ of NL-Group.

\section{Conclusions}

As partially expected by the literature, the two examined groups did not present any relevant difference in terms of pain or disability [2]. Both groups presented a moderate level of pain according to NRS, and a moderate level of disability according either to ODI1.0 or RMQ. In this cohort of AS patients, conversely to the findings reported in literature, sciatic pain had a lower incidence than NL-group. Patients with AS, and a mild to moderate grade of spinal deformity, are not showing worse clinical features than patients affected by NL, and seem not to necessarily require more aggressive treatments than those usually adopted to contain disability in aging patients affected by common NL[3].

\section{Author details \\ 'Servizio di Recupero e Rieducazione Funzionale, Casa di Cura Domus Salutis, Brescia, Italy. ${ }^{2}$ Sezione di Fisiologia Umana, Dipartimento di Scienze Biomediche e Biotecnologie, Università degli Studi di Brescia, Brescia, Italy. ${ }^{3}$ LARIN: Laboratorio di Riabilitazione Neuromuscolare e Attività Fisica Adattata, Brescia, Italy.}

Published: 3 June 2013

\section{References}

1. Aebi M: The adult scoliosis. Eur Spine J 2005, 14(10):925-948.

2. Asher MA, Burton DC: Adolescent idiopathic scoliosis: natural history and long term treatment effects. Scoliosis 2006, 1(1):2. 
3. Di Silvestre M, Lolli F, Bakaloudis G, Parisini P: Dynamic stabilization for degenerative lumbar scoliosis in elderly patients. Spine (Phila Pa 1976) 35(2):227-234.

doi:10.1186/1748-7161-8-S1-011

Cite this article as: Bissolotti et al: Analysis of differences in pain and disability in people with adult scoliosis and nonspecific low back pain. Scoliosis 2013 8(Suppl 1):O11.

Submit your next manuscript to BioMed Central and take full advantage of:

- Convenient online submission

- Thorough peer review

- No space constraints or color figure charges

- Immediate publication on acceptance

- Inclusion in PubMed, CAS, Scopus and Google Scholar

- Research which is freely available for redistribution

Submit your manuscript at www.biomedcentral.com/submit 